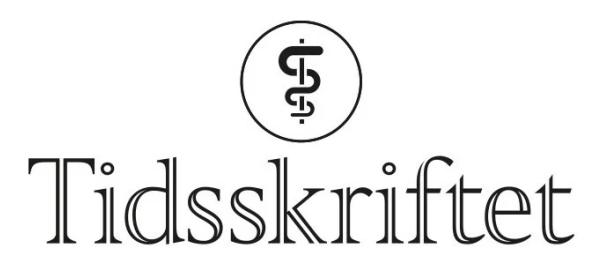

DEN NORSKE LEGEFORENING

\title{
Innbydende om sår
}

\author{
ANMELDELSER
}

\section{ELLEN HEILMANN MODALSLI}

Konstituert overlege, Hudavdelingen, St. Olavs hospital Styremedlem i Norsk interessefaggruppe for sårheling

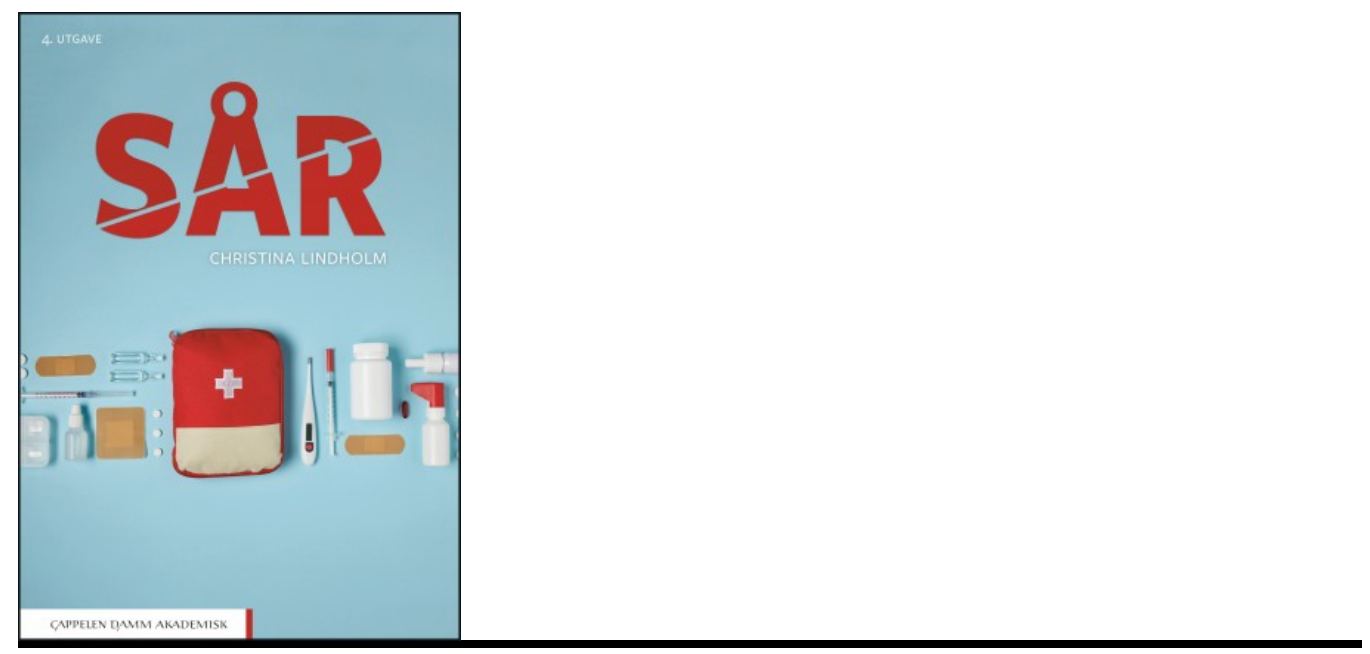

Christina Lindholm

Sår

4. utg. 512 s, tab, ill. Oslo: Cappelen Damm Akademisk, 2020. Pris NOK 689

ISBN 978-82-02-64800-8

Sår har siden tidenes morgen vært en potensielt alvorlig medisinsk tilstand, og sårheling var tidligere ansett som legens viktigste oppgave. Det er funnet nedtegnelser fra omtrent år 3000 f.Kr. som beskriver en rekke ulike såromslag, som for eksempel honning, kvae og rått kjøtt. Men mens de gamle egyptere slikket sine sår i håp om å få sårene til å gro, bygger dagens prinsipper for sårheling på et moderne vitenskapelig fundament.

Forfatteren Christina Lindholm skriver innledningsvis at utgangspunktet for boken nettopp har vært å forsøke å gi et klinisk forankret vitenskapelig overblikk over temaet sår. Hun er professor emerita i klinisk sykepleie, og sår har vært hennes forskningsfelt gjennom en lang karriere. 
Boken er logisk bygget opp og omhandler diagnostikk og behandling av både akutte og kroniske sår, inkludert leggsår, trykksår, fotsår ved diabetes, maligne sår, immunologiske sår og infiserte sår. Boken er skrevet for ulike helsepersonellgrupper med interesse for sår, uavhengig av tidligere erfaring med sårbehandling. I tillegg tar forfatteren opp problemstillinger som er relevante for helsepersonell både i primær- og spesialisthelsetjenesten. Ulike praktiske sårbehandlingsprinsipper som sårrengjøring, fuktighetsbevarende sårheling, sårbandasjer og undertrykksbehandling omtales i egne kapitler. Boken er lettlest, men kan også fungere fint som et teoretisk og praktisk oppslagsverk med informative faktabokser som oppsummerer de viktigste poengene i teksten.

Illustrasjonene er mange og består i hovedsak av en rekke gode kliniske fargebilder, men inneholder også flotte skjematiske fargefigurer som gjør boken svært innbydende og leservennlig. For eksempel er de ulike fasene i sårhelingsprosessen rikt illustrert med informative tegninger og tilpasset tekstmengde.

Hvis du er ute etter en inspirerende og oversiktlig bok om akutte og kroniske sår, vil du la deg begeistre av denne boken. Den bør være lett tilgjengelig på arbeidsplassen for alle leger og sykepleiere som behandler pasienter med sår, både som en introduksjon og som påfyll for de mer erfarne.

Publisert: 4. mai 2020. Tidsskr Nor Legeforen. DOI: 10.4045/tidsskr.20.0208

(C) Tidsskrift for Den norske legeforening 2023. Lastet ned fra tidsskriftet.no 26. april 2023. 